\title{
Belajar Kelompok Pada Mata Pelajaran IPS di Kelas VI Sekolah Dasar
}

\author{
Suprapti ${ }^{1}$, Ch.Erghiezha Ninuk Indrati $K^{2}$ \\ SDN Kedok 2 Turen Kab. Malang ${ }^{1}$, Program Studi Bimbingan dan Konseling \\ Universitas Kanjuruhan Malang ${ }^{2}$ \\ erghiezha@gmail.com
}

\begin{abstract}
Abstrak
Penelitian ini bertujuan agar dalam belajar mata pelajaran IPS bisa menyenangkan sehigga prestasi belajar siswa meningkat dengan menggunakan metode belajar kelompok.Bentuk Penelitian adalah Penelitian Tindakan Kelas yang terdiri dari 4 tahapan, yaitu perencanaan, pelaksanaan tindakan, observasi dan refleksi. Sebagai subyek adalah siswa kelas VI SD yang berjumlah 10 siswa.Berdasarkan penelitian ini di hasilkan bahwa pada siklus I siswa yang menjawab benar mencapai 60,00\% dari 10 siswa yang mengikuti tes. Sementara siswa yang menjawab kurang tepatPersentasenya mencapai 26,67\%. Sedangkan siswa yang menjawab "salah" Persentasenya 20,00\%. Pada silkus II, siswa yang mencapat nilai 2, perolehan nilai hasil belajar siswa meningkat menjadi $66,67 \%$. Sementara itu siswa yang menjawab "kurang tepat" menurun menjadi $22,22 \%$ sedangkan siswa yang menjawab salah menjadi $11,11 \%$.Berdasarkan hasil penelitian tersebut dapat disimpulkan bahwa dengan implementasi belajar kelompok dapat meningkatkan prestasi belajar siswa pada mata pelajaran IPS kelas VI di Sekolah Dasar.
\end{abstract}

Kata kunci: Belajar Kelompok, IPS dan PTK

\begin{abstract}
This study aims to increase the student achievement by using group learning methods. Form of this research is a Classroom Action Research consisting of 4 stages, such as planning, action implementation, observation and reflection. As the subjects are the sixth graders of elementary school with 10 students. Based on this research, it is found that in the first cycle students who answered correctly reached $60.00 \%$ of the 10 students who took the test. While the students who answered less precise percentage reached $26.67 \%$. While students who answered "wrong" Percentage 20.00\%.In second syllus, the students who got the score 2, the value of the students' learning result increased to $66.67 \%$. Meanwhile, students who answered "less precise" decreased to $22.22 \%$ while students who answered wrong to $11.11 \%$. Based on the results of this study can be concluded that with the implementation of group learning can improve student achievement on the social studies class VI in elementary school.
\end{abstract}

Keyword: Group learning, Social Science and PTK 


\section{PENDAHULUAN}

Pencapaian fungsi dan tujuan mata pelajaran IPS di Sekolah Dasar adalah menjadi penting untuk dapat dilaksanakan oleh guru dalam proses belajar mengajar dengan menerapkan prinsip-prinsip pembelajaran fungsi dan tujuan tadi sebagaimana dijelaskan dalam GBPP IPS Sekolah Dasar Tahun 1999 sebagai berikut :

Bahan kajian IPS SD diorganisasikan mulai dari bagian pelajaran yang dekat dan sederhana di sekitar anak ke yang lebih luas dan kompleks.... Tujuan merupakan tolak ukur pengalaman belajar yang harus dicapai oleh siswa setelah mempelajari satu atau beberapa pokok bahasan...... Dalam pelaksanaan kegiatan Belajar mengajar (KBM) guru baik secara fisik, mental (pemikiran dan perasaan), dan sosial serta sesuai dengan tingkat perkembangan Sekolah Dasar (h. 122-123)

Akan tetapi karena bahan belajar IPS yang cakupannya beragam dan luas serta tuntutan kurikulum yang sarat dengan muatan yang harus disampaikan kepada siswa dengan lokasi waktu yang terbatas, guru mengalami kesulitan dalam menyajikan bahan ajar IPS dengan baik, menarik, dan menantang minat belajar siswa, pada akhirnya pembelajaran IPS yang dilaksanakan di Kelas VI Sekolah Dasar adalah dengan melakukan pembelajaran untuk dapat mengejar target.

Tuntutan kurikulum dengan mengandalkan bahan belajar dari buku sumber IPS Kelas VI yang tersedia.Metode mengajar yang selama ini dirasakan kurang cocok untuk menyampaikan materi ceramah sehingga upaya untuk dapat melibatkan siswa dalam kegiatan belajar mengajar IPS masih kurang.

Sementara alat tes yang digunakan hanya menekankan kepada kemampuan siswa sehingga pelaksanaan kegiatan belajar mengajar IPS di Kelas VI Sekolah Dasar yang dilakukan oleh guru berusaha untuk membekali siswa-siswanya dengan bekal pengetahuan yang berupaya untuk bisa menjawab soal tes.

Dengan permasalahan yang digambarkan di atas, salah satu metode belajar mengajar yang dianggap dapat melibatkan siswa aktif dalam kegiatan belajar mengajar IPS di antaranya adalah metode belajar secara berkelompok. Sebab dengan melibatkan siswa secara aktif dalam kegiatan belajar mengajar IPS akan dirasakan berkesan dan bermakna sekaligus dapat mendorong siswa belajar lebih lanjut, melalui belajar secara berkelompok siswa dapat belajar untuk lebih kreatif dalam memecahkan masalah secara bergotong royong bahu membahu dalam mencapai tujuan.

Penelitian tindakan kelas ini akan diterapkan metoda belajar secara berkelompok dalam kegiatan belajar mengajar IPS di Kelas VI Sekolah Dasar melalui tindakantindakan pembelajaran yang terlebih dahulu dirancang sebelum melakukan tindakan tersebut.Masalah penelitian tindakan kelas ini adalah "Apakah metode belajar secara berkelompok dapat meningkatkan hasil belajar siswa dalam mata pelajaran IPS di Kelas VI Sekolah Dasar.

\section{METODE}

Penelitian ini merupakan penelitian Tindakan Kelas (PTK) yang mengacu kepada tindakan guru ketika melaksanakan kegiatan belajar mengajar sebagai upaya untuk memperbaiki kegiatan belajar mengajar berdasarkan refleksi dari kegiatan belajar 
mengajar tersebut.Upaya perbaikan terhadap kegiatan belajar mengajar berdasarkan permasalahan yang ditemui di dalam kelas merupakan tugas dan tanggung jawab guru untuk senantiasa melakukan perubahan-perubahan yang dirasakan perlu dari kegiatan belajar mengajar tersebut.

Dari evaluasi dan pengamatan pada saat melakukan dahulu pembelajaran IPS di Kelas VI maka dalam refleksi akan ditetapkan tindakan-tindakan yang akan dilakukan dalam upaya untuk dapat meningkatkan aktivitas belajar siswa dalam kegiatan belajar mengajar dalam mata pelajaran IPS di Kelas VI melalui penerapan metoda belajar secara berkelompok.Disain penelitian yang dirancang terdiri dari (a) perencanaan tindakan, (b) pelaksanaan tindakan. (c) observasi/refleksi, dan (d) perencanaan tindakan lanjutan (Depdikbud,1999).

Populasi dalam penelitian yaitu siswa UPTD Sekolah Dasar yang duduk di Kelas VI semester I tahun pelajaran 2016/2017. Sampel adalah sebagian atau wakil populasi yang diteliti (Arikunto 1997 : 117) sedangkan Moleong (1989) menyatakan bahwa sampel adalah populasi yang memiliki homogenitas selanjutnya sebagai sampel penelitian, penulis mengambil sebanyak 10 siswa Kelas VI.

Penelitian tindakan kelas ini terdiri dari dua siklus. Pembuatan rencana tindakan dalam setiap siklusnya secara rinci dapat digambarkan sebagai berikut :

\section{Siklus I}

Kegiatan yang dilakukan pada siklus I ini antara lain adalah :

a. setelah melakukan kegiatan observasi awal dalam rangka penjajakan untuk mendapatkan informasi awal tentang keadaan kelas yang akan dijadikan dan diiakukan tindakan, dengan merumuskan persiapan pembelajaran tentang penerapan metoda belajar secara berkelompok untuk meningkatkan aktivitas belajar siswa dalam mata pelajaran Ilmu Pengetahuan Sosial mengenai globalisasi.

b. Pelaksanaan tindakan dari persiapan pembelajaran yang telah dirancang sebelumnya pada tahap pembuatan rencana atau persiapan pembelajaran.

c. Melakukan pengamatan selama kegiatan belajar mengajar berlangsung dengan melakukan pengamatan terutama pada aktivitas belajar siswa selama penerapan belajar secara berkelompok, secara operasional untuk mengenal, mereka dan mendokumentasikan segala hal yang berkaitan dengan hasil dan proses pelaksanaan tindakan ataupun akibat sampingan dari pelaksanaan tindakan.

Tindakan I ini untuk dikomfirmasikan dan dianalisis serta telah dapat mencapai tujuan yang diharapkan atau belum untuk mendapatkan kejelasan dalam merancang dan mempersiapkan tindakan II.

\section{Siklus II}

Kegiatan yang akan dilakukan pada siklus II ini antara lain adalah :

a. Membuat persiapan pembelajaran untuk pelaksanaan tindakan II dengan materi pembelajaran tentang Latar Belakang Berdirinya Perusahaan Asing dengan merencanakan pengelompokan siswa dalam suatu kelompok belajar sebagaimana telah dilakukan pada pelaksanaan tindakan I sebelumnya. 
b. Melaksanakan pembelajaran berdasarkan persiapan pembelajaran untuk pelaksanaan tindakan II dengan menerapkan metoda belajar secara berkelompok yang masingmasing kelompok terdiri dari tiga sampai empat orang siswa. Pembentukan kelompok sepenuhnya diserahkan kepada siswa untuk memilih.

c. Melaksanakan pengamatan selama belajar mengajar berlangsung bersamaan dengan pelaksanaan tindakan dalam upaya untuk mengenal, merekam dan mendokumentasikan setiap hal dari kegiatan yang sedang berlangsung dengan melihal apakah proses dan hasil sesuai dengan yang di harapkan untuk kepentingan dan bahan refleksi.

d. Melakukan pengamatan terhadap aktivitas belajar yang dilakukan siswa selama kegiatan belajar mengajar berlangsung dengan menerapkan metoda belajar secara berkelompok dapat menunjukan aktivitas belajar seperti disiplin, motivasi/semangat belajar, perhatian siswa, komunikasi siswa, kerjasama siswa, aktivitas belajar individu, aktivitas belajar kelompok, dan tanggung jawab siswa.

e. Melakukan evaluasi terhadap hasil kegiatan belajar mengajar yang dicapai siswa. Kegiatan ini dilakukan untuk melihat dan mengukur hasil belajar yang dicapai setelah siswa melakukan kegiatan yang menerapkan metode belajar secara berkelompok.

f. Refleksi II. Pada tahap ini kegiatan yang dilakukan adalah analisis-sintesis, interprestasi, dan eksplanasi (penjelasan) terhadap semua informasi yang diperoleh selama melaksanakan tindakan II berlangsung sekaligus melakukan pengolahan data yang tercatat maupun data yang tidak tercatat tetapi sempat terekam selama melakukan pengamatan ketika melakukan tindakan II untuk dikonfirmasikan dan dianalisis serta dievaluasi sesuai dengan harapan dan apakah tujuan yang dirancang dapat dicapai atau belum untuk mendapatkan kejelasan dalam merancang dan mempersiapkan tindakan berikutnya.

\section{HASIL DAN PEMBAHASAN}

Berdasarkan hasil penjajagan dan observasi belajar mengajar IPS di Kelas VI ini diperoleh hal-hal sebagai berikut :

- Banyak siswa kurang memperhatikan dan memiliki motivasi terhadap mata pelajaran IPS

- Banyak siswa yang bercakap-cakap dengan temannya ketika guru sedang mengajar

- Keterbukaan, kreatifitas dan rasa ingin tahu siswa dengan materi ajar IPS masih belum muncul

- Kerjasama siswa dalam belajar secara berkelompok sangat kurang

- Saling menghargai sesaina teman dalam belajar masih sangat belum tampak

- Saling hormat menghormati dan toleransi kepada teman ketika belajar juga masih rendah

- Aktivitas dan pertisipasi siswa dalam kegiatan belajar mengajar dalam mata pelajaran IPS masih sangat kurang

- Komukasi yang terjalin masih bersifat satu arah yaitu dari guru kepada murid, sedangkan komunikasi dari murid kepada guru masing kurang 
- Banyak siswa yang duduk, dengar dan sesekali mencatat ketika guru sedang mengajar. Dominasi guru dalam belajar mengajar IPS masih sangat menonjol.

Bertolak dari kondisi awal kelas dan alasan-alasan yang dikemukakan di atas peneliti memandang perlu diadakan suatu perbaikan untuk sedikit mengatasi persoalan dan keadaan belajar mengajar IPS ke arah pembelajaran lebih baik dengan berupaya melibatkan siswa dengan kegiatan belajar mengajar supaya peningkatan aktivitas belajar yang diperoleh selama kegiatan belajar mengajar terus berlangsung.

Pelaksanaan Tindakan

Pelaksanaan tindakan penelitian ini menekankan pada penerapan metoda belajar secara berkelompok dalam upaya untuk meningkatkan aktivitas belajar siswa dalam mata pelajaran IPS.Pelaksanaan tindakan penelitian dilakukan tanpa memberitahukan kepada siswa.

\section{Tindakan Pertama}

Pelaksanaan pada siklus pertama ini mengambil materi ajar tentang "Dampak Globalisasi". Pelaksanaan tindakan pertama dengan menerapkan metoda belajar secara berkelompok untuk meningkatkan aktivitas belajar siswa dalam mata pelajaran IPS di Kelas VI SD Negeri Kedok 02 secara umum dapat disimpulkan sebagai berikut :

- Siswa berdo'a dan memberi salam kepada guru, guru mengabsen siswa, dari 10 siswa, dan seluruh siswa hadir semua.

- Guru memberikan penjelasan kepada siswa untuk membentuk kelompok yang setiap kelompoknya tidak lebih dari 3 orang siswa.

- Dalam memilih dan menentukan teman untuk belajar secara kelompok, kebanyakan siswa memilih berdasarkan tempat duduk yang berdekatan dengan dirinya, sehingga teman sebangkunya menjadi teman kelompoknya.

- Setelah seluruh siswa yang hadir dengan jumlah 10 orang siswa tersebut, maka terbentuklah 3 kelompok. Mereka terlihat senang dengan raut muka yang berseri-seri karena mendapatkan teman untuk belajar secara berkelompok.

- Karena tak seperti biasa, mereka tampak antusias dan bersemangat untuk memulai pelajaran ketika guru memberi penjelasan tentang materi IPS yang akan dipelajari.

- Guru berkeliling ke kelompok-kelompok, sambil membimbing, mengarahkan dan membantu siswa (kelompok) yang kesulitan menyelesaikan LKS-nya.

- Guru mengumpulkan LKS dari setiap kelompok. Kemudian membagikan lembar evaluasi (tes) kepada setiap siswa untuk mengukur sejauh mana siswa dapat memahami materi yang telah dipelajari secara berkelompok.

- Setelah setiap kelompok selesai mengerjakan lembar evaluasi (tes), guru mengumpulkannya, kemudian membagikan daftar cek kepada siswa untuk melihat persepsi siswa tentang kegiatan belajar mengajar yang telah mereka alami.

Persentase hasil kelompok belajar siswa dalam mengerjakan LKS dapat dilihal pada tabel 1 di bawah ini. 
Tabel 1.Persentase Hasil Kerja Kelompok dalam Mengerjakan LKS Pada Tindakan I

\begin{tabular}{ccccccc}
\hline \multirow{2}{*}{ Kelompok } & \multicolumn{7}{c}{ Jawaban Soal LKS } \\
\cline { 2 - 8 } & Benar & $\%$ & Salah & $\%$ & Tidak tepat & $\%$ \\
\hline 1 & 3 & $60,00 \%$ & 2 & $40,00 \%$ & 0 & $0,00 \%$ \\
\hline 2 & 4 & $80,00 \%$ & 0 & $0,00 \%$ & 1 & $20,00 \%$ \\
\hline 3 & 2 & $40,00 \%$ & 1 & $20,00 \%$ & 3 & $40,00 \%$ \\
\hline \multicolumn{2}{l}{ Prosentase } & $60,00 \%$ & & $20,00 \%$ & & $20,00 \%$ \\
\hline
\end{tabular}

Berdasarkan hasil pekerjaan kelompok dalam mengerjakan LKS pada pelaksanaan tindakan pertama ini ternyata bahwa Persentase kelompok yang dapat mengerjakan LKS dengan benar adalah 60,0\%. Sementara kelompok yang belum dapat mengerjakan LKS dengan benar adalah 20,00\%. Sedangkan kelompok yang kurang tepat dalam mengisi LKS adalah 20,00\%. Bila menunjuk pada tabel 2 di atas penerapan metoda belajar secara berkelompok juga dapat mencapai tujuan pembelajaran tanpa didominasi guru dalam kegiatan belajar mengajamya.

\section{Tindakan Kedua}

Pelaksanaan tindakan kedua ini materi ajarnya adalah tentang "Latar belakang berdirinya perusahaan asing". Pada pelaksanaan tindakan kedua kegiatan yang dilakukan berdasarkan dengan apa yang telah tercantum dalam pengajaran yang telah dibuat sebelumnya untuk tindakan kedua ini adalah sebagai berikut :

- Siswa berdo'a dan memberi salam kepada guru, kemudian guru mengabsen, dari 10 jumlah siswa, yang hadir 10, sama halnya dengan tindakan pertama

- Guru memberikan pengarahan untuk setiap kelompok tidak lebih dari 3 orang. Pemilihan teman untuk kelompok diserahkan sepenuhnya kepada siswa, dan apabila memungkinkan dalam kelompok itu ada teman dari jenis kelamin yang berbeda.Namun nampaknya dalam memilih teman kelompok dengan jenis kelamin yang berbeda para siswa belum siap.

- Seperti halnya pada tindakan pertama, para siswa memilih teman kelompok berdasarkan tempat duduk yang berdekatan. Dengan bantuan guru akhirnya seluruh siswa dapat tertampung di dalam kelompok belajar walaupun tidak ada satu kelompok pun yang anggotanya berlainan jenis kelamin.

- Dari 10 siswa yang hadir, terbentuk 3 kelompok. Kemudian guru memberikan LKS yang berupa soal kegiatan Latar belakang berdirinya perusahaan asing untuk pelaksanaan tindakan kedua ini. Setiap kelompok ditugasi untuk membahsa dan menyelesaikan LKS berkenaan dengan sub pokok bahasan tentang menceritakan tentang Latar belakang berdirinya perusahaan asing.

- Dalam menyelesaikan dan menjawab LKS, siswa dalam kelompok betul-betul bekerja satu sama lain bahu membahu dan serius untuk bisa menjawab dan mengisi LKS.

- Seperti halnya pada tindakan pertama, guru berkeliling sambil membimbing, mengarahkan dan membantu siswa yang mengalami kesulitan dalam mengerjakan dan meyelesaikan LKS. 
- Selesai mengerjakan LKS guru mengumpulkannya, guru membagikan lembar evaluasi kepada siswa untuk mengetes kemampuan siswa dalam memahami pelajaran yang sudah dipelajari. Guru membagikan daftar cek kepada setiap siswa untuk melihat persepsi siswa tentang kegiatan belajar secara berkelompok yang telah dilaksanakan

Data dan informasi yang diperoleh kelompok belajar siswa dalam mengerjakan LKS pada tindakan kedua adalah sebagai berikut:Persentase hasil kelompok dalam mengerjakan LKS dapat dilihat pada tabel 3 dengan didasarkan atas standar penilaian bahwa kelompok yang benar dalam menyelesaikan LKS diberi bobot 100\%. Sementara yang masih belum dapat menyelesaikan dengan benar diberi bobot sesuai dengan tingkat kebenarannya, misalnya $50 \%$ apabila pengisiannya dianggap setengah (1/2) benar, $75 \%$ apabila pengisiannya dianggap tiga per empat (3/4) benar.

Tabel 2.Persentase Hasil Kerja Kelompok dalam Mengerjakan LKS Pada Tindakan I

\begin{tabular}{ccccccc}
\hline \multirow{2}{*}{ Kelompok } & \multicolumn{6}{c}{ Jawaban Soal LKS } \\
\cline { 2 - 7 } & Benar & \% & Salah & \% & Tidak tepat & $\%$ \\
\hline 1 & 2 & $66,67 \%$ & 0 & $0,00 \%$ & 1 & $33,33 \%$ \\
\hline 2 & 2 & $66,67 \%$ & 0 & $0,00 \%$ & 1 & $33,33 \%$ \\
\hline 3 & 2 & $66,67 \%$ & 1 & $33,33 \%$ & 0 & $0,00 \%$ \\
\hline \multicolumn{2}{l}{ Persentase } & $61,67 \%$ & & $11,11 \%$ & & $22,22 \%$ \\
\hline
\end{tabular}

Hasil Perolehan Nilai Siswa pada Tindakan II

Penilaian hasil belajar siswa didasarkan atas standar penilaian jawaban terhadap soal tes yang berjumlah 3 butir.Setiap butir soal apabila dijawab dengan benar diberi nilai 2 (dua).Sedangkan jawaban yang kurang tepat diberi nilai 1 (satu), dan jawaban yang salah diberi nilai 0 (nol).

Bahwa penerapan metoda belajar secara berkelompok dapat dikatakan cukup efektif untuk mencapai tujuan yang ingin dicapai dalam kegiatan belajar mengajar IPS di Kelas VI SD Negeri Kedok 02.Terbukti dengan hasil tes yang telah dicapai siswa.Persentase daya serap siswa dalam sub pokok bahasan tentang "Latar belakang berdirinya perusahaan asing "cukup tinggi".

Data tentang aktivitas belajar siswa dalam mata pelajaran IPS yang menerapkan metoda belajar secara berkelompok diperoleh melalui instrumen observasi aktivitas belajar siswa yang telah disiapkan dalam upaya untuk mengungkap dan mengetahui aktivitas belajar siswa selama pelaksanaan tindakan II.

Dari pelaksanaan tindakan I dan tindakan II yang menerapkan metoda belajar secara bersama dalam kelompok dalam mata pelajaran IPS di Kelas VI, SD Negeri Kedok 02 diperoleh gambaran padatabel 3. 
Tabel 3.Persentase Perolehan Nilai Hasil Belajar pada siklus I dan siklus II

\begin{tabular}{|c|c|c|c|}
\hline No Soal & Nilai & Siklus I & Siklus II \\
\hline \multirow[t]{3}{*}{1} & 2 & $54,05 \%$ & $91,89 \%$ \\
\hline & 1 & $2,7 \%$ & $5,41 \%$ \\
\hline & 0 & $43,24 \%$ & $2,7 \%$ \\
\hline \multirow[t]{3}{*}{2} & 2 & $75,68 \%$ & $78,38 \%$ \\
\hline & 1 & $8,11 \%$ & $16,22 \%$ \\
\hline & 0 & $16,22 \%$ & $5,41 \%$ \\
\hline \multirow[t]{3}{*}{3} & 2 & $72,97 \%$ & $81,08 \%$ \\
\hline & 1 & $2,7 \%$ & $13,51 \%$ \\
\hline & 0 & $24,32 \%$ & $5,41 \%$ \\
\hline \multirow[t]{3}{*}{4} & 2 & $70,27 \%$ & \\
\hline & 1 & $5,41 \%$ & \\
\hline & 0 & $24,32 \%$ & \\
\hline \multirow[t]{3}{*}{5} & 2 & $64,85 \%$ & \\
\hline & 1 & $5,41 \%$ & \\
\hline & 0 & $29,73 \%$ & \\
\hline
\end{tabular}

Berdasarkan tabel 3 menunjukan bahwa pada siklus I siswa yang mendapat nilai 2 atau jawaban siswanya "benar" mencapai 60,00\% dari 10 siswa yang mengikuti tes. Sementara siswa yang mendapat nilai 1 atau menjawab "kurang tepat" persentasenya mencapai 20,00\%, siswa yang mendapat nilai 0 (nol) atau "salah" persentasenya $20,00 \%$. Pada silkus II, siswa yang mencapai nilai 2, perolehan nilai hasil belajar siswa menjadi $66,67 \%$. Sementara itu siswa yang mendapat nilai 1 atau "kurang tepat" menurun menjadi $22,22 \%$ sedangkan siswa yang menjawab salah menjadi $11,11 \%$.

Belajar secara berkelompok adalah metode mengajar dengan mengelompokan siswa menjadi beberapa kelompok untuk mengerjakan atau membahas tugas yang dibebankan kepada kelompok tersebut. Menurut Moedjono (Mohar Permana dan Mulyani Sumantri, 1999: 1480 disebutkan bahwa metode ini " menitik beratkan kepadainteraksi antara anggota yang lain dalam suatu kelompok guna menyelesaikan tugas-tugas belajar secara bersama-sama" Belajar bersama dalam kelompok menekankan kepada lingkungan belajar untuk bekerja sama dalam mendorong interaksi antar siswa sehingga para siswa akan dapat saling memahamidan saling menghargai satu sama lain dalam hal pandangan-pandangan atau gagasan-gagasan terhadap suatu topic pembelajaran yang akan atau sedang dibelajarkan oleh guru.

Dalam pelaksanakan kegiatan belajar mengajar yang ditetapkan guru melaluimetode belajar secara bersama dalam kelompok siswa dituntut untuk memiliki keterampilan bekerja secara dalam empat bidang kemampuan, yakni : (1) kemampuan membentuk kelompok, (2) kemampuan bekerja bersama dalam kelompok, (3) kemampuan memecahkan masalah sebagai anggota kelompok belajar meliputikemampuan mendefinisikan masalah curah pendapat, mengklarifikasi ide mengkonfirmasikan ide, mengorganisasikan informasi, (4) kepampuan memahami serta menerima perbedaan mencakup kemampuan menerima negoisasi dan pendapat orang lain atau melihat masalah dari sudut pandang yang berbeda.

Penerapan metode belajar secara bersama dalam kelompok menuntut guru untuk dapat mengelompokan siswa secara arif dan bejaksana serta professional yang 
didasarkan kepada : (1) fasilitas yang tersedia untuk mendukung terlaksananya belajar secara bersama dalam kelompok, (2) perbedaan individual setiap siswa dalam hal minat belajar dan kemampuan belajarnya, (3) Jenis tugas dan pekerjaan yang dibebankan, (4) wilayah tempat tinggal siswa, (5) jenis kelamin, (6) memperbesar partisipasi siswa dalam kelompok, dan (7) berdasar pada random (Johar Permana dan Sumantri, 1999).

Tujuan penerapan metode belajar bersama dalam kelompok menurut Moejiono (Permana dan Sumantri, 1999) adalah untuk (1) memupuk kemauan dan kemampuan kerjasama para siswa (2) meningkatkan keterlibatan sosio emosional dan intelektual siswa dalam kegiatan belajar mengajar yang diterapkan guru dan (3) Meningkatkan perhatian kepada proses dan hasil dari kegiatan belajar mengajar secaraberimbang dan professional. Sementara itu, alasan yang melatar belakangi mengapa metode belajar secara bersama dalam kelompok perlu diterapkan dalam pembelajaran dan bahwa (1) siswa dapat bekerja secara bersama dengan anggotanya dalam satumenemukan bahan untuk menyelesaikan dan melaksanakan tugas yang diberikan tersebut, dan (3) agar siswa dapat beraktivitas secara aktif dalam belajarnya.

\section{KESIMPULAN DAN SARAN}

Berdasarkan hasil penelitian yang diperoleh selama melakukan penelitian tindakan kelas tentang penerapan metoda belajar secara bersama dalam kelompok untuk meningkatkan aktivitas belajar siswa dalam mata pelajaran IPS Kelas VI Sekolah Dasar, maka dapat diambil kesimpulan: Pemilihan atau penentuan teman dalam membentuk kelompok belajar adalah didasarkan atas tempat duduk yang berdekatan. Teman yang duduk satu bangku dengan sendirinya menjadi teman kelompok. Kemudian pemilihan teman anggota kelompok belajar dan pemilihan satu orang teman lainnya lagi teman yang paling berdekatan dengan siswa tersebut.Perolehan hasil belajar siswa dalam kegiatan belajar mengajar IPS yang menerapkan metode belajar secara bersama dalam kelompok menunjukkan peningkatan yang signifikan berdasarkan hasil tes yang dilakukan pada siswa setelah mengikuti kegiatan belajar mengajar.Disarankan belajar kelompok dipergunakan dalam proses pembelajaran supaya prestasi siswa bisa meningkat

\section{DAFTAR PUSTAKA}

Departemen Pendidikan Dan Kebudayaan (1999).Penyempurnaan Penyesuaian Kurikulum1999.Jakarta: Depdikbud

Kasbolah, Kasihani (1998/1999) Penelitian Tindakan Kelas, Jakarta: Ditjen Dikti, Depdikbud

Permana J, dan Sumantri M. (1999).Strategi Belajar Mengajar. Jakarta: Ditjen Dikti, Depdikbud

Rasyidin, Waini. (2000).Layanan Mutu Guru Dalam Upaya Meningkatkan Proses Pembelajaran Siswa SD. Bandung, Laporan Penelitian: Tidak diterbitkan.

Undang-undang Nomor 20. (2003). Tentang Sistem Pendidikan Nasional, Bandung, Fokusmedia 